\title{
Hypertension risk factors among patients visiting Community Health Centre 1 in South Denpasar
}

\author{
N P D Witari ${ }^{1 *}$, A A G Y Kusuma ${ }^{1}$, W Semadha ${ }^{1}$ \\ ${ }^{1}$ Faculty of Medicine and Health Sciences, Universitas Warmadewa, Denpasar, Bali
}

*diahwitari@gmail.com

\begin{abstract}
Hypertension becomes an alarming problem in almost all parts of the world, especially developing countries like Indonesia. This study describes risk factors associated with hypertension in patients who visited public health center I South Denpasar. Case control study was used as research design by using 84 samples ( 42 cases: 42 control). Data were collected through interviews with a questionnaire of IPAQ, food recall and physical examination of blood pressure. Sampling technique was using consecutive sampling. Multivariate analysis indicated an adjusted odds ratio as follows: salt intake $\geq 6$ grams of salt per day (OR: 4,718; 95\% CI: 1,6248-13,707), family history of hypertension (OR: 4,156; 95\% CI: 1,487-11,612) and physical activity (OR; 4,143 95\% CI: 1,486-11,551). While the independent variables that are not proven as risk factors for hypertension are gender (OR: 0.817; 95\% CI: 0.338-1.974) and age (OR: 1,370; 95\% CI: 0,259-7,249). The results of this study was expected to be an input for public health center I South Denpasar that promotive and preventive programs of disease is needed to reduce the occurrence of hypertension in the work area of public health center I South Denpasar
\end{abstract}

Keyword : Hypertension, Community Health.

\section{Introduction}

Hypertension (the silent killer) is a worrying problem in almost all parts of the world, especially developing countries like Indonesia. The status of this disease as the silent killer if it is not controlled or handled properly can lead to various kinds of complications and even death $[1,2,3,4,5]$. In addition, hypertension is the number three cause of death in Indonesia after tuberculosis and stroke, which is $6.7 \%$ of deaths in all ages [6]. Cases of hypertension in Bali are the second largest cases with 114,421 cases [7]. The number of patient with hypertension is increasing with many of hypertensive patients have an uncontrolled blood pressure [8].

Hypertension is one of the many diseases that affect the heart and blood vessels which are characterized by increased systolic blood pressure $\geq 140 \mathrm{mmHg}$ and / or diastolic $\geq 90 \mathrm{mmHg}$ after two separate measurements in a state of adequate rest [8]. Hypertension can be effectively controlled through certain factors. Hypertension determinants are divided into 2 categories including: unmodified risk factors (family history, age, and sex) and controllable risk factors (high sodium diet, excess weight, stress, physical activity and smoking) $[3,9,10]$. The body has a compensatory mechanism in regulating blood pressure to maintain blood pressure stability and prevent blood pressure increases caused by circulatory disorders.

In general, blood pressure in the body is influenced by two things, namely volume and total peripheral resistance. If there is a disturbance on one of these variables that is not compensated it will cause hypertension. The blood pressure compensation mechanism is 
grouped into slow type and fast type. The fast compensation system involves cardiovascular reflexes through the nervous system, chemoreceptor reflexes, ischemic response, central nervous system originating from the atrium, and smooth muscle pulmonary arteries. While the slow reaction compensation mechanism involves the hormone angiotensin and vasopressin in controlling fluid transfer between the capillary circulation and the interstitial cavity [11]

This research was conducted to describe the risk factors associated with hypertension in patients visiting Public Health Center I, South Denpasar.

\section{Method}

The study was conducted at Public Health Center I, South Denpasar in August October 2017 using a case-control study design, by grouping the sample into 2 groups, namely the case group (hypertensive patients) and the control group (not hypertension). The division of this grouping aims to analyze the relationship between several risk factors (age, sex, hereditary factors, physical activity and salt consumption) with the incidence of hypertension in the work area of Public Health Center I, South Denpasar.

The study involved 84 respondents who were selected using the consecutive sampling technique obtained from the registration of patients in South Denpasar Public Health Center I in the range of August-October 2017 which was chosen as the sample in which case samples and control samples selection were taken from the register on the same day. Patients have to meet several criteria to be used as samples, that is fulfilling inclusion criteria.

The inclusion criteria include patients diagnosed with hypertension (cases) and not hypertension (controls) by doctors or health workers at the South Denpasar Public Health Center I listed in the registration book from August to October 2017, patients must live in the working area of South Denpasar Public Health Center I.

\section{Results And Discussion}

The data obtained showed that respondents aged $\geq 60$ years were more in the case group while respondents $<60$ years were more in the control group. Viewed from the sex of the respondents in this study female respondents were greater than the number of male respondents in the case and control groups. Based on the level of education, the majority of cases were respondents with high school graduates totaling 15 people $(35.2 \%)$ while those in the control group the highest education level was tertiary graduates with 17 respondents $(40.2 \%)$. Based on the type of work, there were more groups in the other occupational categories. 28 respondents $(66.7 \%)$ in the case group had a history of hypertension in the family, compared with 17 respondents $(40.5 \%)$ in the control group who had a history of hypertension in their family. From the physical activities carried out daily, 27 respondents $(64.3 \%)$ on the case group carried out physical activities in the low category while in the control group the activities in the low category were 16 respondents $(38.1 \%)$. Based on the amount of salt consumption, in the case group 25 respondents $(59.5 \%)$ were categorized as consuming gram 6 grams of salt per day and in the control group only 17 respondents (40.5\%) consumed $\geq 6$ grams of salt per day. The results of univariate analysis will be presented in the table 1 below. 
Table 1. The results of univariate analysis

\begin{tabular}{ccc}
\hline \multicolumn{1}{c}{ Characteristic } & Case (\%) $(\mathbf{n}=\mathbf{4 2})$ & Control (\%) (42) \\
\hline Age & $24(57,1)$ & $15(35.7)$ \\
<60 years old 60 years old & $18(42,9)$ & $27(64.3)$ \\
Gender & & \\
Male & $15(35,7)$ & $17(40.5)$ \\
Female & $27(64,3)$ & $25(59.5)$ \\
Latest Education & & \\
Not finished & $3(7,1)$ & $2(4.8)$ \\
Elementary & $10(23,8)$ & $9(21.4)$ \\
School & $0(0)$ & $0(0)$ \\
Junior High & $15(35,7)$ & $14(33.3)$ \\
School & $14(33,3)$ & $17(40.5)$ \\
Senior High & & \\
School & & \\
College & & $4(9.5)$ \\
Occupation & $3(7,1)$ & $9(21.4)$ \\
Government employee & $10(23,8)$ & $12(28.6)$ \\
Private employee & $12(28,6)$ & $17(40.5)$ \\
Entepreneur & $17(40,5$ & \\
Others & & $17(40.5)$ \\
Famil yhistory of & $25(59.5)$ \\
Hypertension & $14(33,3)$ & \\
Yes & & $16(38.1)$ \\
No & $27(64,3)$ & $26(61.9)$ \\
Physical Activity & $15(35,7)$ & \\
Low & $25(59,5)$ & \\
High & $17(40,5)$ & \\
Salt Consumption & & \\
$\geq 6$ gram & & \\
<6 gram & & \\
\hline & & \\
\hline
\end{tabular}

The bivariate analysis was used to determine the relationship of risk factors for hypertension which consisted of age, sex, family history, physical activity and salt consumption with the incidence of hypertension in patients visiting South Denpasar Public Health Center I. The bivariate analysis that used in this study was chi square test. Significance test was seen using 95\% CI ( $\mathrm{P}$ value <0,05). The results showed that age, family history, physical activity and salt consumption had a relationship with an increased risk of hypertension in patients visiting South Denpasar Public Health Center I. The results of bivariate analysis will be presented in the table 2 below

Table 2. The results of Bivariate Analysis

\begin{tabular}{|c|c|c|c|c|c|c|}
\hline & Variable & $\begin{array}{c}\text { Case } \\
(n=42)\end{array}$ & $\begin{array}{c}\text { Control } \\
(n=42)\end{array}$ & $\begin{array}{c}\text { OR } \\
\text { Crude }\end{array}$ & $\begin{array}{c}95 \% \text { CI } \\
\text { OR }\end{array}$ & $\mathbf{p}$ \\
\hline \multicolumn{7}{|l|}{ Age } \\
\hline & $\geq 60$ years old & $24(57.1 \%)$ & $15(35.7 \%)$ & 2.400 & $0.997-5.778$ & $0.049 *$ \\
\hline & $<60$ years old & $18(42.9 \%)$ & $27(64.3 \%)$ & & & \\
\hline
\end{tabular}




\begin{tabular}{|c|c|c|c|c|c|}
\hline Variable & $\begin{array}{c}\text { Case } \\
(n=42)\end{array}$ & $\begin{array}{c}\begin{array}{c}\text { Control } \\
(n=42)\end{array} \\
\end{array}$ & $\begin{array}{c}\text { OR } \\
\text { Crude }\end{array}$ & $\begin{array}{c}95 \% \mathrm{CI} \\
\text { OR }\end{array}$ & $\mathbf{p}$ \\
\hline \multicolumn{6}{|l|}{ Gender } \\
\hline Male & $15(35.7 \%)$ & $17(40.5 \%)$ & 0.817 & $0.338-1.974$ & 0.653 \\
\hline Female & $27(64,3 \%)$ & $25(59,5 \%)$ & & & \\
\hline \multirow{2}{*}{\multicolumn{6}{|c|}{$\begin{array}{l}\text { Family history of } \\
\text { Hypertension }\end{array}$}} \\
\hline & & & & & \\
\hline Yes & $28(66.7 \%)$ & $17(40.5 \%)$ & 2.941 & $1.208-7.159$ & $0.016 *$ \\
\hline No & $14(33.3 \%)$ & $25(59.5 \%)$ & & & \\
\hline \multicolumn{6}{|c|}{ Physical Activity } \\
\hline Low & $27(64.3 \%)$ & $16(38.1 \%)$ & 2.925 & $1.205-7.099$ & $0.016^{*}$ \\
\hline High & $14(33.3 \%)$ & $26(61.9 \%)$ & & & \\
\hline \multicolumn{6}{|c|}{ Salt Consumption } \\
\hline$\geq 6$ gram & $25(59.5 \%)$ & $15(35.7 \%)$ & 2.647 & $1.096-6.395$ & $0.029 *$ \\
\hline$<6$ gram & $17(40.5 \%)$ & $27(64.3 \%)$ & & & \\
\hline
\end{tabular}

Based on the results of multivariate analysis there were three variables associated with the incidence of hypertension in patients visiting South Denpasar Health Center I which were salt consumption ( $\mathrm{p}$-value $=0.004)$, family history of hypertension $(\mathrm{p}$-value $=0.007)$ and physical activity ( $\mathrm{p}$ value $=0.007$ ). The results of multivariate analysis will be presented in the table 3 below.

Table 3. The results of Multivariate Analysis

\begin{tabular}{cccc}
\hline Variable & OR & $\begin{array}{c}\mathbf{9 5 \%} \mathbf{C I} \\
\text { OR }\end{array}$ & $\mathbf{p}$ \\
\hline Salt Consumption $(\geq 6 /<6$ gram $)$ & 4.718 & $1.624-13.707$ & $0.004^{*}$ \\
Age & 1.370 & $0.259-7.249$ & 0.711 \\
History of Hypertension & 4.156 & $1.487-11.612$ & $0.007^{*}$ \\
Physical Activity & 4.143 & $1.486-11.551$ & $0.007^{*}$ \\
\hline
\end{tabular}

\subsection{Family History of Hypertension}

The family history of hypertension was proven to be a risk factor for hypertension with reference to the results of multivariate analysis obtaining a value of $p=0.007$; AOR $=4.156$ and $95 \% \mathrm{CI}=1.48711,612$. These results indicated that subjects from families with hypertension have 4.1 times higher risk of hypertension compared to subjects who have no history of hypertension in the family. Genetic factors in the family affect a person's risk of suffering from an illness. In hypertension, this is related to an increase in intracellular sodium levels and a low ratio of potassium to sodium caused by several genes that influence sodium reabsorption by the kidneys [12].

\subsection{Physical activity}

Based on multivariate analysis related to physical activity with the incidence of hypertension, it was shown that mild physical activity increased the risk of hypertension, seen from $\mathrm{p}=0.007$. $\mathrm{OR}=4.143$ and $95 \% \mathrm{CI}=1.486-11.551$, this value indicates that respondents who did mild physical activity had a 4.1 chance of suffering from hypertension compared to respondents who did physical activity in heavy categories [13]. These results are in line with the results of previous studies which stated that regular physical activity helps increase blood flow directly to produce nitric oxide (NO). Nitric oxide stimulates the formation of endothelial derive relaxing factor (EDRF) which functions as vasodilation or arterial dilation $[14,15]$ and makes it more elastic [16]. 


\subsection{Excess Salt Consumption}

The results of multivariate analysis with regression tests showed that the level of salt consumption $\geq 6$ grams became a risk factor for the incidence of hypertension $p=0.005$; AOR $=4,718 ; 95 \%$ CI: $1.6248-13.707$ which means that respondents who consumed salt $\geq 6$ grams per day had 4.7 times the risk of suffering from hypertension when compared to those who consumed $<6$ grams of salt per day. This result is in line with the research conducted by $\mathrm{He}, \mathrm{Li}$ and Macgregor, 2013, who said that by reducing salt consumption in respondents at a given time able to reduce $4.18 \mathrm{~mm} \mathrm{Hg}$ (95\% confidence interval -5.18 to -3.18$)$ in systole and decreased $2.06 \mathrm{~mm} \mathrm{Hg}$ (95\% confidence interval -2.67 to 1.45) on diastole [17].

\section{Conclusions}

Based on the results of multivariate analysis of hypertension risk factors in patients visiting South Denpasar Health Center I, the results showed that the incidence of hypertension was influenced by a family history of hypertension, low physical activity and high salt consumption.

\section{References}

[1] Awoke A, Awoke T, Alemu S, Megabiaw, B 2012 Prevalence and associated factors of hypertension among adults in Gondar Northwest Ethiopia : a community based cross-sectional study $\mathrm{p} 2-7$.

[2] Gao Y, Chen G, Tian H, Lin L, Lu J, Weng J, Jia W 2013 Prevalence of Hypertension in China: A Cross-Sectional Study 8(6)

[3] Zhang J, Huang Q, Yu M, Cha X, Li J, Yuan Y, Wei T 2013 Prevalence Awareness Medication Control and Risk Factors Associated with Hypertension in Bai Ethnic Group in Rural China : The Yunnan Minority Eye Study 8(8) p 1-9

[4] Manuscript A, 2014 NIH Public Access 31(7) p 1364-71

[5] Khanam M A, Lindeboom W, Razzaque A, Niessen L, Milton A H 2015 Prevalence and determinants of pre- hypertension and hypertension among the adults in rural Bangladesh: findings from a community-based study $\mathrm{p}$ 1-9

[6] Margarita Y, Pincen, Andi, Marcella E R B K, Bambang S 2013 Kadar Kolesterol Total dan Tekanan Darah Orang Dewasa Indonesia Jurnal Kesehatan Masyarakat Nasional 8(2) p 79-84

[7] Dinas Kesehatan Provinsi Bali, 2015 Profil Kesehatan Provinsi Bali Tahun

[8] Pusat Data dan Informasi Kementerian Kesehatan RI, P D dan I K K R 2013 Info Dantin Hipertensi

[9] Nuraini B 2015 Risk factors of hypertension 4 p 10-19.

[10] Lionakis N 2012 Hypertension in the elderly World Journal of Cardiology 4(5) p.135

[11]Longo D L, Fauci A S, Kasper D L 2012 Harrison's: Principles of Internal Medicine McGrawHill Medical United State of America 18 p 2042-2527.

[12] Kartikasari A N, Chasani S, Ismail A 2012 Faktor Risiko Hipertensi pada Masyarakat di Desa Kabongan Kidul, Kabupaten Rembang Program Studi Pendidikan Dokter Fakultas Kedokteran Universitas Diponegoro

[13] Wahiduddin, Hasrin M , Rismayanti 2013 Faktor Risiko Kejadian Hipertensi di Kecamatan 
[14] Sutanto 2010 Cekal (Cegah dan Tangkal) Penyakit Modern : Hipertensi, Stroke, Jantung, Kolesterol, dan Diabetes (gejala- gejala, Pencegahan dan Pengendalian), Yogyakarta: ANDI Yogyakarta

[15] Sharman J E, La Gerche A, Coombes J S 2014 Exercise and Cardiovascular Risk in Patients With Hypertension American journal of hypertension

[16] Suiraoka 2012 Penyakit Degeneratif Mengenal Mencegah dan Mengurangi Faktor Risiko 9 Penyakit Degeneratif, Yogyakarta: Nuha Medika.

[17]Feng J H, Jiafu L, Graham A, MacGregor 2013 Effect of Longer Term Modest Salt Reduction on Blood Pressure : Cochrane Systematic Review and Meta Analysis of Randomised Trials 